UDC $371.3:: 811.163 .41 ' 243$

$371.3:: 811.111 ' 243$

DOI 10.18485/primling.2015.16.7

\author{
Dr Gordana Janjušević Leković \\ Gimnazija „Niko Rolović“ \\ Bar, Crna Gora
}

\title{
OBLAST LEKSIKE I LEKSIKOLOGIJE KAO POLAZIŠTE ZA INTERDISCIPLINARNU KORELACIJU U NASTAVI
}

Sažetak: U radu se analiziraju različite mogućnosti povezivanja predmetnih sadržaja u okviru nastave maternjeg jezika i književnosti u gimnaziji, s tim što je u fokusu leksika i leksikologija kao dio nauke o jeziku. U kontekstu proučavanja leksičkog blaga domaćeg jezika moguće je uspostaviti interdisciplinarnu korelaciju sa najrazličitijim predmetnim sadržajima (strani jezici, društvene i prirodne nauke, umjetnosti, vještine), što se u nastavnoj praksi i dokazuje. U jednom odjeljku biće riječi o lingvističkim projektima u školi, sa posebnim osvrtom na skorašnje istraživanje upotrebe anglicizama, kompjuterske leksike i internet slenga u jeziku mladih.

Ključne riječi: leksika, leksikografija, integrisana nastava, maternji jezik, strani jezik, anglicizam, Internet sleng

\section{Uvod}

Bez obzira na različite stavove lingvista o statusu leksike unutar jezičkog sistema, proučavanje ovog aspekta jezika ima ne mali značaj za lingvistička istraživanja, učenje (kako maternjeg tako i stranih) jezika, ali i za obrazovni proces i naučno-istraživački rad uopšte.

U ovom radu polazimo od hipoteze da nema naučne discipline i školskog predmetnog programa koji se ne može dovesti u vezu sa nastavom maternjeg jezika i književnosti. Oblast leksike i leksikologije predstavlja odlično polazište za najrazličitije vidove integrisane nastave.

Polazeći od toga da su specifičnosti leksike pisaca vrlo povezane sa tematikom i značenjima umjetničkog teksta, prvo ćemo osvijetliti mogućnosti unutarpredmetne korelacije (jezik - književnost; leksikologija - semantika - stilistika), a zatim, preko programskih sadržaja koji se odnose na prevodnu književnost, ukazaćemo na potrebu za integrisanom nastavom maternjeg i stranih jezika. Interakcija sa stranim jezicima podrazumijeva se kada je u nastavi maternjeg jezika riječ o onom sloju leksike koji čine tuđice, pozajmljenice. Takođe, u zavisnosti od pomenutog umjetničkog odabira leksičke građe i tematike književnog teksta, istražujemo mogućnosti interakcije u nastavi maternjeg jezika sa 
različitim sadržajima. Otvaraju se interesantne mogućnosti višestruke interdisciplinarne korelacije (npr. maternji jezik - strani jezik - književnost - biologija/geografija/istorijal psihologija/sociologija), što je prilika za unapređivanje i provjeravanje sposobnosti učenika da se služe rečnicima različitog tipa.

U posebnom dijelu rada biće riječi o lingvističkim projektima u školi koji su idealna prilika za povezivanje srodnih i manje srodnih predmetnih sadržaja i obično su vrlo inspirativni kao izvorište budućih ideja za integrisanje različitih oblasti u nastavi.Ovoga puta istražujemo upotrebu novijih anglicizama u jeziku mladih. Učesnici u lingvističkom istraživanju su gimnazijalci - i kao anketirani ispitanici i kao istraživači. Na osnovu rezultata istraživanja osmišljavaju se oblici unutarpredmetne i međupredmetne korelacije u nastavi.

Istraživanjima u okviru ovog rada prethodi analiza predmetnih programa u gimnaziji.

\section{Sadržaji u nastavi maternjeg jezika i književnosti i mogućnosti korelacije sa drugim predmetnim programima}

Nesumnjivo je da nastava jezika i književnosti, možda i više nego bilo koji drugi nastavni sadržaj pojedinačno, otvara neslućene mogućnosti za unutarpredmetnu i međupredmetnu korelaciju. Jedan od ključnih principa u modernom pristupu nastavi upućuje na potrebnu interferenciju programskih sadržaja kako bi se ostvario jedan od glavnih ciljeva - integralno obrazovanje, primjenjivost i transfer znanja.

Ovakvo povezivanje može se vršiti planski, u skladu sa preporučenim korelacijama iz zvaničnih predmetnih programa (o čemu će kasnije biti riječi), ali mogu se dešavati i spontano, naročito kada je jezik i književnost u pitanju.

Za ovaj drugi način - neposrednog, neplaniranog (i uspjelog) metodičkog postupka navodimo ovdje jedan primjer. Poslije čitanja romana Rani jadi Danila Kiša, u toku interpretacije završnice djela i značenja koja izviru iz odjeljka pod naslovom Eolska har$f a$ - učenici su dobili zadatak da prelistaju odgovarajuće enciklopedije i leksikone i pronađu muzički termin eolska harfa, kako bi imali jasniju predstavu o instrumentu, a time i bolje razumjeli Kišovu metaforu. Prvo su pronašli ovo značenje služeći se raznim izvorima, a onda su na času dobili jedan višejezični rječnik muzičkih termina (Vlastimir Peričić, Višejezični rečnik muzičkih termina. Srpska akademija nauka i umetnosti, Zavod za udžbenike, Univerzitet umetnosti. Beograd, 2008) iz kojeg su saznali kako se to kaže/ piše na italijanskom, francuskom, engleskom, njemačkom, ruskom i češkom jeziku (,„Eolova harfa (instrument sa žicama koje trepere pod dejstvom vetra) / I arpa $f$ eolia, a.d'Eolo / F harpe $f$. Éolienne, h.d'Éole / E Aeolian harp / lyre, wind h. / N Äolsharfe $f$. Windharfe $f$, Wetterharfe $f$, Geisterharfe $f /$ R эолова арфа $f$ / Č Aeolová/Aiolová harfa f“, n. d., 79).

Tako smo, polazeći od jednog terminološkog izraza, uspostavili prvo interdisciplinarnu korelaciju sa predmetom Muzička umjetnost, a onda i sa stranim jezicima (s tim što, kad je o jezicima / jeziku riječ - pojam interdisciplinarnost postaje relativna kategorija: humboltovski rečeno, umjesno je smatrati da svekoliki ljudski rod ima samo jedan jezik, kao i da svaki čovjek ima svoj poseban jezik). Potreba da se uporedi eolska harfa Andreasa Sama sa onom pravom iz enciklopedija i rječnika vraća nas intradiscipli- 
narnoj sferi gdje konstatujemo autentičnu, vanrednu atmosferu i emociju i veoma visok estetski domet Kišovog teksta. Potreba za vizuelizacijom poetske slike upućuje na korelaciju sa predmetom Likovna umjetnost, a ,prava“ eolska harfa evocira antiku i povezivanje priče sa istorijom i istorijom umjetnosti. Tako su jedno djelo i u njemu jedan pojam - termin, otvorili puteve za različite oblike rada i povezivanje obrazovnih sadržaja.

Treba ovdje već na početku istaći da neki gimnazijski predmetni programi ovakve metodičke pristupe ne prepuštaju slučaju niti pak kreativnosti do koje dolazi kada ideja iskrsne „sama“, već eksplicitno ističu da se naznačene korelacije iz predmetnog programa moraju realizovati. (Da li to istovremeno znači da neke druge, takođe logične i smislene, nije uputno realizovati?) Dakle - kod određenog broja predmetnih programa (npr. Istorija, Sociologija) istaknut je zahtjev koji zvuči pomalo rigidno i naredbodavno, naročito kada detaljnije analiziramo programske sadržaje i ustvrdimo da naznačene korelacije, od programa do programa, nisu najpreciznije usaglašene.

\section{Predmetni programi: preporučene i moguće korelacije}

Uvid u predmetne programe za opštu gimnaziju (u Crnoj Gori) nameće zaključak da predviđena polja međupredmetne korelacije nisu najbolje sinhronizovana, tj. da je negdje izostala puna saradnja između komisija za pojedine predmete koje su odlučivale o programskim sadržajima i predlagale korelaciju među nastavnim predmetima. Tako imamo situaciju da u Predmetnom programu za maternji jezik ${ }^{1}$ ni na jednom mjestu nije predviđena korelacija sa stranim jezicima u okviru druge nastavne oblasti - nastave književnosti, već isključivo u okviru nastave jezika ${ }^{2}$, iako Program otvara brojne mogućnosti da se, u kontekstu pojmova / sadržaja kao što su SVJETSKA KNJIŽEVNOST, PREVODNA KNJIŽEVNOST - organizuju vježbe izražajnog čitanja i prevođenja izvornog umjetničkog teksta, upoređivanja različitih prevoda i sl., što ujedno podrazumijeva i leksičku, i sintaksičku, i stilsku vježbu u okviru nastave maternjeg i stranih jezika. Posebno treba istaći učinak koji se na ovaj način postiže kada govorimo o interkulturalnosti i interkulturnoj kompetenciji, koju recepcija (ali i prevođenje) književnoumjetničkog teksta i te kako unapređuje. Evidentno je, međutim, (navodno u cilju pospješivanja funkcionalne pismenosti), da se posljednjih decenija favorizuje neumjetnički tekst, a taj trend je primjetan i u programskim sadržajima za maternji jezik - što je po svemu sudeći jednako pogrešno kao i doskorašnje odsustvo neumjetničkog teksta u okviru nastave ovog predmeta.

1 Predmetni program Crnogorski jezik i književnost za I,II,III,IV razred opšte gimnazije, Ministarstvo prosvjete i sporta, Zavod za školstvo, Podgorica, 2011.

Napomena:

Program je nastao prilagođavanjem prethodnog, koji je pod nazivom Predmetni program - Maternji jezik i književnost, I, II, III i IV razred opšte gimnazije - podgorički Zavod za školstvo odobrio nekoliko godina ranije, dok se i sam predmet u školama izučavao pod tim nazivom (i uz mogućnost dopisivanja jednog od četiri imena lingvistički istog jezika, po izboru). Iako novi predmetni program nosi naziv Crnogorski jezik književnost, sam predmet se u crnogorskim školama od 2011/12. izučava pod četvoroimenim nazivom: Crnogorski-srpski, bosanski, hrvatski jezik i književnost.

2 Program za svaki razred sastoji se iz dva dijela, naslovljena kao PRVA NASTAVNA OBLAST - JEZIK i DRUGA NASTAVNA OBLAST - KNJIŽEVNOST 
Međutim, ono što je u kontekstu naslovljene teme interesantno jeste mogućnost koju gimnazijski program maternjeg jezika otvara za povezivanje sa nastavnim sadržajima stranih jezika u okviru nastavne jedinice Nauka o jeziku i njene discipline (str. 18), gdje se u koloni pod naslovom Korelacija upućuje na sljedeće: „Strani jezici (termini: argo, žargon /francuski/, sleng /engleski/)" Istina, ovakvo povezivanje prije bismo mogli očekivati u kontekstu nastavnog sadržaja Raslojavanje jezika, ali nešto ipak treba prepustiti i inventivnosti onih koji su u samoj nastavi i sa učenicima neposredno realizuju program. Takođe, na strani 14 (PRVA NASTAVNA OBLAST - JEZIK, I razred), gdje nisu popunjene kolone Pojmovi/sadržaji i Korelacija, u koloni pod naslovom Operativni ciljevi piše: „Razvija vještinu čitanja, razumijevanja i analize neumjetničkih tekstova (naučnih i publicističkih) i sposobnost da samostalno piše tekstove“, a uporedo, u koloni Aktivnosti predviđa se da učenici nakon čitanja „objašnjavaju značenja nepoznate riječi u kontekstu, pogledaju u rječnik/leksikon“.

Ovo je jedno važno programsko polazište za povezivanje sa bezmalo svim nastavnim predmetima odnosno gimnazijskim programskim sadržajima, zato što pomenuti FS zaista otvaraju beskrajne mogućnosti u tom smislu. Ne postoji nauka, umjetnost, vještina koja ne bi mogla biti tema jednog takvog neumjetničkog teksta, pa se tu polje korelacije već po sebi otvara za realizaciju u nastavi. (Tim prije čudi da je kolona Korelacija na str. 14 ostala prazna). Dakle, treba izdvojiti funkcionalne stilove kao odlično polazište za korelaciju sa svim programskim sadržajima u okviru nastave maternjeg jezika, pri čemu se uvijek može poči od leksike korišćene u tekstu.

Još jedno nezaobilazno programsko polazište za svestranu korelaciju u nastavi maternjeg jezika sa svim ostalim nastavnim predmetima predstavlja sama oblast (tema) Leksikologija.

(PRVA NASTAVNA OBLAST - JEZIK, III razred, str. 66). Ni ovdje u zvaničnom Predmetnom programu za maternji jezik nije popunjena kolona pod naslovom Korelacija, što je takođe iznenađujuće jer upravo u okviru ove oblasti prirodno je povezivati nastavu maternjeg sa stranim jezicima, a onda i sa svim ostalim različitim predmetnim sadržajima, radi potrebnog transfera znanja i ostvarivanja principa integralnog obrazovanja - a to su načela na koja se sastavljači i donosioci predmetnih programa redovno pozivaju i rado ih ističu. Međutim, u koloni gdje se navode preporučene aktivnosti na času, između ostalog, piše da učenici „navode termine iz različitih nauka“6, „istražuju i zapisuju frazeološke jedinice iz svakodnevnog života“, „prepoznaju terminologiju određene nauke ili neke druge djelatnosti na odabranim tekstovima“, ,prave rječnike sinonima, antonima“", „traže pojmove u odgovarajućim rječnicima".

U koloni Pojmovi - sadržaji navode se i termini: rječnik, leksikografija, leksem, leksička semantika; lokalizam, regionalizam, dijalektizam, internacionalizam, arhaizam, varvarizam, neologizam, žargonizam, vulgarizam, familijarizam, kolokvijalizam i sl.

Jasno je da u objašnjavanju svakog konkretnog pojma treba poći od (kon)teksta u užem i širem smislu, te da treba doći do odgovarajućeg rječnika (leksikona), pri čemu je i intradisciplinarna i interdisciplinarna korelacija neizbježna.

Ovdje ćemo navesti samo par primjera.

Kako se u istom razredu (III gimnazije) u okviru obavezne lektire proučava djelo Seobe Miloša Crnjanskog - sasvim je prikladno dati učenicima zadatak da sačine rječnik arhaizama na osnovu ovog teksta. Dalja korelacija sa predmetnim sadržajima iz 
istorije bila bi vrlo prirodna (istina, predmetni program iz ovog predmeta često ne prati istovremeno onaj istorijski period koji je tema u okviru nastave književnosti, bilo u smislu periodizacije same književnosti, bilo kao istorijski period koji obrađuje literarni tekst, ali to ne znači da učenici ne mogu u izvjesnoj mjeri da se posvete istraživanju istorijskog konteksta nekog umjetničkog pravca ili pak, kao u ovom slučaju - književnog djela). Takođe, s obzirom na temu (migracije, seobe) u djelu je frekventna upotreba toponima i geografskih pojmova, što otvara polje korelacije i sa geografijom, a s obzirom na tanano psihološko nijansiranje kolektivnog i individualnih likova u kontekstu istorijskih seoba - povezivanje sa određenim sadržajima u oblasti psihologije takođe je primjereno (uz mogućnost sačinjavanja rječnika apstraktnih imenica i drugih riječi kojima se dočarava atmosfera teksta i emotivna stanja junaka). Da ne govorimo o tome koliko je uputna korelacija sa nastavnim predmetom Likovna umjetnost $\mathrm{s}$ obzirom na raskošni lirizam vizuelnih poetskih slika u romanu. Najzad, djelo je ekranizovano, tako da je i korelacija književnost - filmska umjetnost (koja se smatra unutarpredmetnom) takođe interesantna i potrebna.

Roman Kad su cvetale tikve Dragoslava Mihailovića pogodan je za istraživanje različitih slojeva leksike (npr. žargonizama, lokalizama, vulgarizama), pri čemu je povezivanje sa sadržajima iz soiologije (društveni slojevi, stratifikacija društva), istorije (istorijski okvir priče), pa i sporta (sportska terminologija - glavni junak je bokser) vrlo preporučljiv metodički postupak.

Djela Bore Stankovića (Koštana, Nečista krv) pogodna su za istraživanje dijalektizama i lokalizama, ali i za povezivanje sa sadržajima iz psihologije (jezik i psihološka uvjerljivost, autentičnost književnog lika), biologije (genealogija glavne junakinje romana), sociologije (porijeklo bogatstva i klasnog statusa Sofkine porodice).

Bogatstvo leksike koja ukazuje na vanredno poznavanje flore i faune, te odgovarajućih pojmova-naziva iz oblasti botanike i zoologije u romanima Mihaila Lalića otvaraju mogućnost za sačinjavanje rječnika, a zatim i korelaciju sa predmetima Biologija i Latinski jezik.

Mali ornitološki leksikon može se sačiniti u okviru interpretacije Njegoševog teksta (,Tek sokolu prvo perje nikne / On ne može više mirovati / Nego svoje razmeće gnijezdo; / Grabeć slamku jednu i po jednu / S njom put neba bježi cijučući. / Sve je ovo nekakva nauka!“” „Za kokošku i orla ne pitam, /No što strepi laf od guske, kaži?“ „Hoćah ubit jednu kukavicu / A ža mi je fišek oštetiti.“ „Ne valja se biti kukavica. / Oli ne znaš, jadi te ne znali /Da su ono šćeri Lazareve“ „Doleće ni jato jarebicah“ „Utekle su k vama da uteku / a nijesu da ih pokoljete“ „Ćud lisičja ne treba kurjaku! / Što jastrebu oće naočali?““ „Domamili pa ih pohvatali / Jednu našu braću sokolove / Dalmatince i hrabre Hrvate.“ „Slabostma smo zemlji privezani, / Ništava je, nego tvrda veza. /Ali tice te su najslabije / Lovi svjetlost lisičijeh očih /Nego orla krijući gledaju.“ „Gergeleze, krilo od sokola“; „Kuda si mi uletio, / moj sokole“; „Grlo joj je čista fildiša /B'jele ruke krila labuda“ „Soko hoće visoku liticu / Soko traži ticu jarebicu, / Jarebica tanka i plašiva / Ma tijela kako vatra živa“-iz Gorskog vijenca Petra II Petrovića Njegoša). Razumije se, zgusnuta Njegoševa metaforika traži odgonetanje, svaka ptica ima svoje poetsko značenje, nijansirano u različitim kontekstima. Pri tom, upućivanje i ovdje na korelaciju sa sadržajima iz nastavnog predmeta Biologija može da bude interesantno i doprinese boljem razumijevanju pjesničkog figurativnog izraza. 


\section{Lingvistički projekti u školi}

Učenicima povremeno treba dati priliku da istražuju u oblasti jezika, naravno shodno njihovim interesovanjima.

U Gimnaziji u Baru do sada su realizovana dva lingvistička projekta. Prvi, Žargon mladih (autori projekta mr Gordana Leković i Slavica Vujović, pedagog, u saradnji sa odjeljenjem III-2 školske 2002/2003. godine), naišao je na veliko interesovanje i rađen je sa istinskim entuzijazmom. (Podršku istraživanju pružio je i lingvista Ranko Bugarski, koji je bio počasni gost našeg projekta.) U okviru istraživanja omladinskog žargona učenici su imali različite zadatke: da prouče literaturu o jezičkom raslojavanju i objasne šta je sociolekt, razgovaraju sa lingvistima (intervjuisana je prof.dr Slavica Perović sa Instituta za strane jezike u Podgorici), anketiraju pripadnike različitih generacija i obrade dobijene podatke o stavovima prema jeziku, glume u pozorišnom komadu (tekst sa žargonskom leksikom, napisan za tu priliku), sačine Mali rečnik omladinskog žargona. Učenici su predstavili javnosti projekat koji je rezultirao i odgovarajućom publikacijom.

Danas je omladinski žargon „obogaćen“ novijim anglicizmima („kompjuterska leksika") koje, istina, ne koriste samo mladi, ali su u njihovom govoru ipak najviše prisutni i često žargonski „obrađeni“, sa pečatom kreacije u jeziku. Nedavno smo u istoj školi obavili jedno preliminarno istraživanje s ciljem da utvrdimo koliko (i koje) novije anglicizme mladi upotrebljavaju, šta misle o eventualnoj upotrebi domaćih riječi umjesto „uvezenih“ i sl. U okviru ovog istraživanja učenici su upućivani na određene sadržaje iz nastavnih predmeta Informatika i Engleski jezik, što je bio još jedan zanimljiv vid interdisciplinarne korelacije.

\subsection{Lingvističko istraživanje u okviru projekta Upotreba anglicizama $i$ kompjuterske leksike u internet slengu mladih}

\subsubsection{Rezultati ankete}

Anketa koju smo nedavno realizovali u Gimnaziji u Baru obuhvatila je tri odjeljenja (II i III razred), podijeljena u dvije grupe. Ispitanici iz prve grupe odgovarali su na sljedeća pitanja i zahtjeve:

1. Navedi novije anglicizme kojih se trenutno možeš sjetiti.

2. Koje od tih riječi ti koristiš u komunikaciji sa vršnjacima?

3. Pokušaj da prevedeš navedene anglicizme, odnosno da pronađeš odgovarajuće domaće riječi i izraze koji bi ih mogli zamijeniti. Pored svakog prevedenog anglicizma napiši da li ti se više dopada strana ili domaća riječ.

Gotovo svi ispitanici (približno 98\%) ostavili su svoj potpis na anketnom listu, a malobrojni pojedinci ostali su anonimni (što je takođe u skladu sa dogovorom koji je prethodio anketiranju). Potpisani učesnici pomogli su nam da konstatujemo da su se istih riječi sjetili oni koji se inače međusobno intenzivnije druže i posjećuju iste sajtove i društvene mreže. Ovo je naročito upadljivo kada je riječ o anglicizmima kojih se trenutno mogao sjetiti mali broj ispitanika (manje od $20 \%$ anketiranih). Takođe, potvrđeno je očekivanje da će se bolji učenici prihvatiti prevođenja „neprevodivih“ novijih anglicizama i biti u tom poslu uspješniji i precizniji. (Anketiranim gimnazijalcima dopušteno je da ne odgovore na sva pitanja, odnosno da biraju pitanja na koja će odgovoriti.) 
4.1.2. Na zahtjev da navedu novije anglicizme kojih se trenutno mogu sjetiti odazvali su se svi ispitanici.

Određene riječi upadljivo su prisutne u ovim spiskovima. Sljedeća tabela ${ }^{3}$ će ovo pokazati u procentima:

\begin{tabular}{|c|c|c|c|c|c|c|c|}
\hline $\begin{array}{l}\text { lajkovati / } \\
\text { lajkovanje/ like }\end{array}$ & $89 \%$ & ekstra & $11 \%$ & LOL/lol & $11 \%$ & see $U$ & $5 \%$ \\
\hline šerovati/šerovanje & $68 \%$ & fajl & $11 \%$ & $\begin{array}{l}\text { surfovati / } \\
\text { surfovanje }\end{array}$ & $11 \%$ & see you soon & $5 \%$ \\
\hline ok/okej & $63 \%$ & yes & $11 \%$ & tačskrin & $11 \%$ & smajli & $5 \%$ \\
\hline cool/kul & $63 \%$ & hi & $11 \%$ & start & $11 \%$ & snapovati & $5 \%$ \\
\hline tagovati / tag & $53 \%$ & no & $11 \%$ & anlajkovati & $5 \%$ & sorry & $5 \%$ \\
\hline tvitovati/twitowati & $47 \%$ & online /onlajn & $11 \%$ & bagovati & $5 \%$ & sry & $5 \%$ \\
\hline OMG & $42 \%$ & kiss & $11 \%$ & basket & $5 \%$ & start & $5 \%$ \\
\hline čatvati/četovati & $32 \%$ & ily / I love U & $11 \%$ & haštag & $5 \%$ & btw & $5 \%$ \\
\hline $\begin{array}{l}\text { postovati/ } \\
\text { postovanje }\end{array}$ & $32 \%$ & bot & $11 \%$ & comment & $5 \%$ & stil & $5 \%$ \\
\hline fejk & $32 \%$ & intervju & $11 \%$ & čekirati & $5 \%$ & stop & $5 \%$ \\
\hline $\begin{array}{l}\text { foulovati (folovati / } \\
\text { falovati) }\end{array}$ & $26 \%$ & dokumentarac* & $11 \%$ & $\begin{array}{l}\text { fashion } \\
\text { week }\end{array}$ & $5 \%$ & subscribeovati & $5 \%$ \\
\hline fejl & $21 \%$ & dislike & $11 \%$ & facebook & $5 \%$ & TMI & $5 \%$ \\
\hline net & $21 \%$ & kompjuter & $11 \%$ & fast food & $5 \%$ & trejler & $5 \%$ \\
\hline top & $21 \%$ & help & $11 \%$ & fotošut & $5 \%$ & sajlens & $5 \%$ \\
\hline wtf & $21 \%$ & fudbal & $11 \%$ & full & $5 \%$ & ty & $5 \%$ \\
\hline selfie /selfi & $21 \%$ & veb & $11 \%$ & anfalovati & $5 \%$ & ofc & $5 \%$ \\
\hline Šoping & $21 \%$ & bye & $11 \%$ & hakovati & $5 \%$ & vokabular* & $5 \%$ \\
\hline ASAP & $16 \%$ & reporter* & $11 \%$ & $\begin{array}{l}\text { happy } \\
\text { birthday }\end{array}$ & $5 \%$ & ups & $5 \%$ \\
\hline rašovati & $16 \%$ & program* & $11 \%$ & inboks & $5 \%$ & $\begin{array}{l}\text { tb(,text } \\
\text { back") }^{\prime \prime}\end{array}$ & $5 \%$ \\
\hline happy & $16 \%$ & parti & $11 \%$ & lip-stick & $5 \%$ & Snapchat & $5 \%$ \\
\hline $\operatorname{tn} x$ & $16 \%$ & please/pliz/pls & $16 \%$ & menšnovati & $5 \%$ & Instagram & $5 \%$ \\
\hline afk & $11 \%$ & puš & $11 \%$ & konektovati & $5 \%$ & Twitter & $5 \%$ \\
\hline bf & $11 \%$ & super & $11 \%$ & off & $5 \%$ & BFF & $5 \%$ \\
\hline
\end{tabular}

Zapažamo sljedeće:

a) Pravopisna rješenja variraju kako od jednog do drugog ispitanika tako i od jednog do drugog anglicizma koje bilježi isti ispitanik.

Primjećujemo izvornu englesku ortografiju u najvećem broju primjera. Riječ „kul“, prilično frekventnu na ovim spiskovima anglicizama, samo je jedan ispitanik napisao kao adaptiranu; svi ostali zapisali su je u skladu sa izvornim pravopisom: cool.

3 U tabelu su unijete riječi koje su anketirani gimnazijalci navodili, sa svim eventualnim greškama i pravopisnim nedosljednostima. Komentar slijedi u tekstu ispod tabele. 
Međutim, riječi „lajkovati“, „,̌erovati“, „,tagovati“, „,tvitovati“”, ulavnom su pisali u skladu sa ortografskom normom srpskog jezika; indikativno je to što (uglavnom) iste ove riječi navode kao anglicizme koje sami najčešće koriste.

Nailazimo i na pravopisne greške i nesnalaženja u pisanju ,poluadaptiranih““4 anglicizama (npr. nalazimo oblik „twitowati“, „,subskribeovati“ i ,,sbskrojbovati“ i sl., premda su ovakvi primjeri rijetki).

b) Učesnici su kao anglicizme navodili i riječi koje su u englesku leksiku uplovile iz drugih jezika (npr. ,,vokabular“, ,dokumentarac“, ,,program“5). S obzirom na to da je puteve riječi, njihovu etimologiju, katkad veoma teško pratiti (obratiti pažnju, na primjer, na riječ „,reporter“6 ${ }^{\text {, }}$ koja se takođe nalazi na spisku anglicizama kod anketiranih gimnazijalaca), kao i na okolnost da je engleski vodeći svjetski jezik u savremenom svijetu i prvi strani jezik koji mladi uče - nije iznenađujuće što je po njihovo „sluhu“ i jezičkom osjećanju gotovo svaka strana riječ, ukoliko u sličnom obliku postoji u engleskom, jednostavno - anglicizam. Nije isključeno da markantno prisustvo lekseme „program“ u kompjuterskoj terminologiji prepunoj anglicizama, na primjer, asocira na engleski jezik i navodi neke na zaključak da je i ova riječ anglicizam, iako to izvorno nije. Takođe, riječ stil ima latinsko porijeklo i u englesku leksiku ulazi preko francuskog jezika, ali imamo je ovdje zabilježenu kao „anglicizam“, pri čemu ne treba zanemariti činjenicu da engleski donosi novo značenje ovog termina, makar kada je riječ o sferi kompjuterske leksike ${ }^{7}$.

Takođe, anketirani gimnazijalci su kao „novije anglicizme“ navodili i neke riječi koje se teško mogu ubrojiti u novije (fudbal, basket, intervju).

Iako među zabilježenim primjerima preovlađuju anglicizmi iz kompjuterske terminologije, ima i onih koji to nisu (lip-stick, fashion week).

4 v. npr. Bugarski 2006: 18,19

5 vokabular, -ara m. (lat. vocabularium prema vocabulum reč) 1. fond reči u jednom jeziku, rečnik. 2. sve reči koje koristi i razume neki pojedinac ili društvena grupa (Klajn - Šipka, 2008: 274)

dokumentaran, -rna, -rno (nlat. documentarius, v.dokument) koji se zasniva na dokumentima, koji služi kao zapis ili dokaz čega dokumentarni film film u kome se bez igrane radnje i glumaca prikazuju pojave i događaji iz života (ibid., 387)

dokumen(a)t, -nta m, mn dokumenti, gen. mn. dokumenata (lat. documentum primer, pouka, prema docere poučavati) 1.spis, isprava, službeni akt 2. ono što se može koristiti kao dokaz ili istorijski izvor 3. rač. tekst sačuvan na kompjuterskom hard-disku u obliku jednog fajla. (ibid.)

program, -a m. mn. programi (grč. programma prema prographein prethodno napisati) 1.plan, nacrt, osnova rada 2.utvrđivanje načela i ciljeva političke stranke, ministarstva, vlade i dr. 3. a. raspored po kome će se navoditi muzička dela ili druge tačke na nekoj priredbi, predstavi, koncertu. b. spisak učesnika i tema na nekom skupu. (...) 6. rač. niz uputstava kompjuteru za obavljanje određenih operacija. (pod rednim brojevima od 1. do 7. navodi se više različitih, najčešće bliskih značenja; ibid., 999, 1000)

up. Fr. Vocabulaire m. , vocable m., Documentaire a., document m., programme m.; engl. vocabulary, documentary, document, program(me)

6 Imenicu reporter i glagol report nalazimo u engleskom jeziku (v.npr.Sezamov 2007: 647); na engleski jezik naslanja se i objašnjenje njenog značenja u srpskom jeziku kod nekih leksikografa (v. npr. Klajn-Sipka, 2008: 1070; međutim, isti autori pozivaju se kod bliskoznačne riječi reportirati na njeno francusko porijeklo u engleskom jeziku: ,engl.report od fr. reporter“, ibid.) U francuskom postoji ista imenica (reporter m. reporter, izvjestilac), ali kao glagol od kojeg je imenica izvedena reporter ima prepoznatljivo francusko, tj.romansko značenje: prenijeti, premjestiti i sl. (otuda i prenositi u smislu izvijestiti); report $\mathrm{m}$. - prenos, prenošenje (v. npr. Šamić, 1977); i u samoj francuskoj riječi prisutan je latinski korijen.

7 „Style - operacija koja se u programu Word koristi za određivanje stilova za fontove ili kompletan izgled dokumenta." (Kosić, 2001: 130) 
Upravo gore pomenute „nepoznanice“, između ostalog, bile su tema na časovima integrisane nastave maternjeg i stranih jezika, gdje su se učenici upućivali na jezičku normu u dijelu koji se tiče pravopisa, kao i na korišćenje različitih tipova rječnika u kojima mogu naći neke odgovore kada je u pitanju porijeklo i značenje određenih riječi.

\subsubsection{Upotreba novijih anglicizama u jezičkoj praksi mladih}

Većina ispitanika odgovorila je i na pitanje koje od navedenih riječi oni lično koriste. Najčešći odgovori glase: „većinu“, „sve“, „skoro sve“. Bilo je i konkretnijih, preciznijih:

„Od ovih riječi koje sam napisala koristim skoro svaku sa vršnjacima, a najviše: omg, ok, cool, thx."

„Uglavnom koristim sve gore navedene riječi, zbog velike ekspanzije društvenih mreža (facebook, twitter, instagram, snapchat,...)“

„Koristim okej, tagovati, lajkovati, anlajkovati.“

„OK, start, lajkovati, fudbal, kompjuter.“

„Fast food, lajkovati.“

„OK, fejl, fejk, hp, folovati, bot, net, cool, tagovati, super.“

„OK (rijetko), čatovati (rijetko), lajkovati, tagovati." (U drugom dijelu odgovora navodi da ne koristi većinu riječi kojih se sjetila, npr. bagovati, off, cool, šerovati, fejk.)

„,Kompjuter, lajkovati; tagovati (rijetko), konektovati (ponekad).“ (U nastavku ispitanica naglašava da ne koristi sljedeće anglicizme: čatovati, šerovati, kul, fejk.) špežbuk."

„...lajkovati, postovati, omg, tagovati, top, trop, jer najčešće koristim mesenđer i

U ovom posljednjem odgovoru zapažamo prepoznatljive žargonske intervencije na fonološkom nivou u oblicima ,mesenđer“ i ,špežbuk“. Očigledno je da se kompjuterska leksika kao jedan noviji standardnojezički sloj stručne terminološke leksike (žargon struke) polako useljava u prostor omladinskog slenga (žargona mladih kao nestandardnog jezičkog varijeteta), te da se riječi i skraćenice ovog tipa koriste u komunikaciji mladih i u drugim i drugačijim kontekstima, bez obzira na medij komunikacije.

\subsubsection{Prevođenje $i$ „,(an)lajkovanje“ anglicizama}

Većina anketiranih nije se u ovoj anketi ogledala u prevođenju anglicizama. Od preostalog broja učesnika (oko 35\%) većina je prevela samo par riječi, uglavnom onih čije značenje je manje-više svima poznato. Takođe mali broj anketiranih odgovarao je na pitanje da li je u konkretnim primjerima bolje izabrati anglicizam ili domaću riječ, a oni koji su odgovorili - uglavnom daju prednost upotrebi anglicizama.

Ponekad nespretni pokušaji prevođenja otkrivaju učinak različitih uticaja koji mijenjaju i sam doživljaj i osjećanje maternjeg jezika kod pripadnika mlade generacije.

Nalazimo, na primjer, i ove prevode anglicizama , na naš jezik“: „,kul (cool) super“; ,ekstra - super“; „OK - okej“. Dakle, engleske riječi toliko su se odomaćile u njihovom rječniku da ih prevode - drugim engleskim riječima. 
Najčešći prevodi jesu sljedeći: tag, tagovati - označiti; OK - u redu; lajkovati sviđati se; šerovati - podijeliti; čatovati - dopisivati se.

Dvije gimnazijalke su značenje riječi tagovati objasnile kao: „označiti na slici“ i „označiti nekoga na dragoj slici“ (učenica je dodala nacrtano srce). Takođe, riječ čatovati/ četovati, koju obično prevode kao „dopisivati se“ - na jednom mjestu je prevedena kao „ćakulati“.

Gotovo svi ispitanici (koji su se uopšte o tome izjasnili) kažu da im se anglicizmi više sviđaju od odgovarajućih domaćih riječi.

Već iz navedenih pokušaja prevođenja, u koje su gimnazijalci upleli sopstvene vrijednosne i estetske sudove o upotrebi anglicizmima, odnosno domaćih riječi koje bi ih mogle zamijeniti - lako je zaključiti da prevagu odnose riječi i izrazi iz engleskog jezika. Navodimo na kraju ovog odjeljka još neka razmišljanja naših gimnazijalaca, iskazana posebno, na kraju ankete:

„S obzirom na to da su anglicizmi već dugo prisutni u našem jeziku i da se vrlo često koriste, već smo se i srodili sa njima. Čudno nam zvuči kad treba da „prevedemo“ te riječi. Sa jedne strane gledano, bolje bi bilo da koristimo naše riječi i da obogaćujemo rječnik našeg jezika, međutim, bolje zvuči anglicizam.“”

„Volim da koristim kompjuterski žargon. Zanimljivo mi je kada sa bratom komuniciram koristeći te riječi, a stariji nas samo gledaju... i pojma nemaju o čemu mi to..."

Tajnovitost, kao i sama potreba za tim da se unutar grupe (u ovom slučaju generacijske) koristi leksika nerazumljiva drugima, onima izvan tog društvenog kruga - još jednom potvrđuje da kompjuterski stručni žargon, internet-terminologija kao dio jezičkog standarda - prelazi u sferu omladinskog slenga kao novi, internet sleng, nestandardni žargon generacije koja (ako izuzmemo stručnjake i rijetke znalce među starijom populacijom) - najviše i koristi nove tehnologije.

Upravo ovaj fenomen bio je predmet i povod za korelaciju u nastavi jezika i psihologije. U okviru ovog oblika integrisane nastave mlade ljude smo podsticali na razmišljanje o psihološkim osnovama iz kojih se rađa motivacija da se unutar socijalne grupe kao što je njihova (generacijska) izgrađuje određeni stil u jeziku, način izražavanja koji ih istovremeno povezuje (međusobno) i izdvaja u odnosu na neke druge društvene grupe. Međutim, ovdje treba istaći i neke druge vidove motivacije koji su u literaturi opisani kao „upotreba engleskog jezika (koja) je prvenstveno sociopsihološki motivisana, potrebom da se neko predstavi kao osoba kojoj je bliska anglofona kultura (...), pomodarskim sklonostima, kao i jednostavnom mentalnom lenošću da se u uslovima kada su engleske reči svuda oko nas na dohvat ruke potraži adekvatni prevodni ekvivalent u rečnicima i ostalim jezičkim priručnicima“" (Mišić Ilić 2011: 79).

\subsection{Stavovi prema jeziku (rezultati drugog dijela istraživanja)}

Druga grupa ispitanika (gimnazijalci II i III razreda) imala je zadatak da napiše kraći esej na zadatu temu - Šta mislim o načinu izražavanja mladih danas. Interesantno je koliko se njihov odnos i vrijednosni sud o sopstvenom jeziku mijenja kada treba mišljenje da iskažu na ovaj način: dakle - ne odgovorima na direktna i konkretna pitanja, već unekoliko uopšteno i sa određene distance koja makar u nekoj mjeri podrazumijeva analitički pristup, više objektivnosti i kritičkog promišljanja. Ovdje je većina učesnika 
izrazila negativne stavove koji se mogu svesti na nekoliko ključnih: 1) Mladi danas imaju oskudan rječnik. 2) Malo čitaju, a i kada čitaju - kvalitet tog izbora je vrlo upitan. 3) Loš uticaj medija.

Izdvojićemo neka razmišljanja: laka štiva.“

„Moji vršnjaci malo čitaju. Ako bi i pročitali nešto to bi se uglavnom svodilo na

„Često se koriste strani izrazi, npr. lajkovati, tvitovati i sl. Smatram da bi trebalo što više da koristimo domaće izraze.“

„Mladi imaju izrazito škrt rječnik“

„Rječnik mladih sve je siromašniji. Sporazumijevaju se skraćenicama.“

„Kako tješimo druga ili drugaricu: 'Biće sve OK. Svega mi.'“

Međutim, mladi ističu i prednosti modernog doba:

„Mislim da je jezik mladih veoma bogat i da mladi mogu da govore o bilo kojim temama čak i na više načina. “ „To je novi stil koji je karakterističan za našu generaciju.“

Nameće se zaključak da je odnos mladih prema novom stilu izražavanja, čitalačkim navikama (tj.odsustvu istih) te sve učestalijoj upotrebi anglicizama iz kompjuterskog žargona - prilično ambivalentan. Sa jedne strane, stil generacije njima samima se dopada, engleski zaista osjećaju kao „odomaćeni strani jezik“ (v. Prćić 2005: 14-21), ali svjesni su i druge strane medalje, a ona uključuje i prisustvo engleskog u domaćem jeziku kao oblik lijenosti i „pomodarstva“ (ibid., 84-87). Uostalom, ,jezik se ne čuva zabranama“ (v. Bugarski 2005: 263-267), žargonska upotreba zaista i „obogaćuje“ i ,,naružuje jezik“: „čini oboje“ (v. Bugarski 2006:11) - tako da je i pomenuta ambivalencija u stavovima mladih prema sopstvenom jeziku u nekom smislu prirodna i očekivana.

\section{Zaključci}

Oblast leksike i leksikologije predstavlja odlično polazište za uspostavljanje najrazličitijih vidova interdisciplinarne i intradisciplinarne korelacije u nastavi, što se u praksi i dokazuje.

Polazeći od rječnika (različiti leksički slojevi - npr. domaće riječi različitih domena upotrebe, stručna i naučna terminologija, tuđice / pozajmljenice kao poseban leksički sloj domaćeg jezika i sl.) - razmotrili smo i na primjerima pokazali mogućnosti povezivanja sadržaja u oblasti maternjeg i stranih jezika, biologije, umjetnosti, geografije, informatike, sociologije, psihologije.

Lingvistička istraživanja kao interdisciplinarni projekti u školi predstavljaju odličan način povezivanja različitih oblasti, a rezultati istraživanja ukazuju na nove puteve i mogućnosti integrisane nastave. 


\section{Literatura:}

Bugarski R. (1986). Lingvistika u primeni. Beograd: Zavod za udžbenike i nastavna sredstva / drugo izd. 1996, ponovljeno 2007.

Bugarski R. (2005). Jezik i kultura. Beograd: Biblioteka XX vek.

Bugarski R. (2006). Žargon - lingvistička studija. Drugo, prerađeno i prošireno izdanje. Beograd: Biblioteka XX vek.

Klajn I., Šipka M. 2008. Veliki rečnik stranih reči i izraza. Treće dopunjeno i ispravljeno izdanje. Novi Sad: Prometej.

Kosić Đ. (2001). Rečnik kompjuterskih termina. U: Kompjuter u praksi. Beograd, Naučna d.o.o, 119-131

Mišić Ilić B. (2011). Anglosrpski i serglish: dva varijeteta srpskog jezika nastala pod uticajem engleskog. U: Primenjena lingvistika u čast Ranka Bugarskog / Applied linguistics in honour of Ranko Bugarski. Urednica Vera Vasić. Novi Sad: Društvo za primenjenu lingvistiku Srbije, 71-93

Peričić V. (2008). Višejezični rečnik muzičkih termina. Beograd: Srpska akademija nauka i umetnosti, Zavod za udžbenike, Univerzitet umetnosti.

Predmetni program Crnogorski jezik i književnost za I,II,III,IV razred opšte gimnazije. (2011). Podgorica: Ministarstvo prosvjete i sporta, Zavod za školstvo.

Prćić T. (2005). Engleski u srpskom. Novi Sad: Zmaj.

Sezamov englesko-srpski rečnik. Priredila prof. Suzana Rowe. Zrenjanin: SEZAM BOOK, 2007. (Beograd: Beoknjiga)

\section{Gordana Janjušević Leković}

\section{THE FIELD OF LEXICON AND LEXICOLOGY AS A STARTING POINT FOR INTERDISCIPLINARY CORRELATION IN TEACHING}

Summary: This paper analyses various possibilities for making connections between the subject content in the teaching of the mother tongue and literature in high school, and lexicon and lexicography as part of linguistics. Regardless of the varying views of linguists concerning the status of lexicon within the linguistic system, the study of this aspect of language has major significance for linguistic research, teaching of (both native and foreign) language, but also for the educational process and scientific research in general. Starting from the fact that the specificity of the lexicon of a writer is largely connected with the theme and meaning of an artistic text, we highlighted the possibilities for an intercorrelation (language - literature, lexicography - semantics - stylistics), and then, through the syllabus related to translated literature, we pointed to the need for integrated teaching of native and foreign languages. The interaction with foreign languages takes place when studying loanwords in the lexicon of the mother tongue. We conclude that there is no scientific discipline and syllabus which cannot be correlated with the teaching of the mother tongue and literature, in the context of studying the lexical treasure of the local language.

Key words: lexicon, lexicography, integrated teaching, native language, foreign language, anglicism, internet slang 